\title{
ANÁLISE CRÍTICA DO INSTITUTO DO COMPROMISSO ADMINISTRATIVO PREVISTO NO ARTIGO 23, DO PROJETO DE LEI DO SENADO N. 349/2015, QUE TRATA DA ALTERAÇÃO DA LINDB
}

\section{CRITICAL ANALYSIS PROVIDED FOR ADMINISTRATIVE COMMITMENT OF THE INSTITUTE IN ARTICLE 23 , OF BILL N. 349/2015, OF SENATE, WHICH DEALS WITH THE CHANGE OF BIRBL}

\author{
${ }^{1}$ Raul Miguel Freitas De Oliveira \\ ${ }^{2}$ Dirceu Giglio Pereira
}

\section{RESUMO}

O presente artigo se propõe a analisar a faculdade prevista no artigo $23, \S 2^{\circ}$, do Projeto de Lei do Senado n. 349/2015, de a autoridade administrativa requerer autorização judicial para celebrar compromisso com os interessados, acordos administrativos. Como resultado de tais discussões é possível aferir que a propositura, ao facultar a submissão do ajuste à jurisdição voluntária, mostra-se político e juridicamente inadequada, porque em descompasso com o fenômeno da desjudicialização, e, ainda, por desconsiderar as competências da advocacia pública, os limites da jurisdição voluntária, e os princípios de separação de poderes e republicano.

Palavras-chave: Acordos administrativos, Autorização judicial, Desjudicialização, Competências da advocacia pública, Limites da jurisdição voluntária, Princípios de separação de poderes e republicano

\begin{abstract}
This article aims to analyze the option provided for in Article 23, § 2, of the PLS n. 349/2015 of the administrative authority to require judicial authorization to enter into engagement with stakeholders, administrative agreements. As a result of such discussions is possible to infer that the bringing, by allowing the submission of adjustment to voluntary jurisdiction, it appears to be political and legally inadequate because of step with the non-judicialisation phenomenon, and also to disregard the powers of public advocacy, the limits of voluntary jurisdiction and the principles of separation of powers and republican.
\end{abstract}

Keywords: Administrative agreements, Judicial authorization, Non-judicialisation, The powers of public advocacy, The limits of the voluntary jurisdiction, Principles of separation of powers and republican

\footnotetext{
${ }^{1}$ Doutor em Direito do Estado pela Universidade de São Paulo - USP, São Paulo (Brasil). Professor doutor membro comissão da Faculdade de Direito da Universidade de São Paulo de Ribeirão Preto - USP/RP, São Paulo (Brasil).E-mail: ramilfo@usp.br

${ }^{2}$ Mestrando em Direito pela Universidade de São Paulo de Ribeirão Preto - USP/RP, São Paulo (Brasil). E-mail: dirceugiglio@usp.br
} 


\section{INTRODUÇÃO}

Em 09 de maio de 2015, foi deflagrado processo legislativo no âmbito do Senado Federal, mediante Projeto de Lei n. ${ }^{\circ}$ 349/2015, de autoria do Senador Antonio Anastasia, pelo qual se pretende a inclusão, na Lei de Introdução às Normas do Direito Brasileiro - LINDB (Decreto-lei n. ${ }^{\circ}$ 4.657, de 1942), de disposições sobre segurança jurídica e eficiência na criação e aplicação do direito público.

A propositura inclui na Lei de Introdução às Normas de Direito Brasileiro, segundo explicação constante de sua ementa, dispositivos (artigos 20 a 29) referentes à criação, interpretação e aplicação de normas administrativas.

Conforme justificativa do referido projeto de lei do Senado, o país desenvolveu, ao longo dos anos, inúmeros instrumentos jurídicos de regulação da atividade administrativa, incluindo-se aí, o controle externo e interno do desempenho da Administração Pública.

Entretanto, conforme motivado pelo senador propositor, apesar de tal incremento da legislação, ocorreu paralelamente um retrocesso em termos de segurança jurídica, com aumento da incerteza e imprevisibilidade, colocando em risco os ganhos da estabilidade institucional.

A propositura legislativa em análise, ainda na forma da sua justificativa, tem por escopo elevar os níveis de segurança jurídica e de eficiência na criação e aplicação do direito público.

A propositura, por seu turno, baseou-se em pré-projeto de autoria dos doutrinadores administrativistas Carlos Ari Sundfeld e Floriano de Azevedo Marques Neto, que justificaram a necessidade da criação de tais regras jurídicas a fim de se incluir no ordenamento jurídico "medidas para neutralizar importantes fatores de distorção da atividade jurídico-decisória pública” (SUNDFELD; MARQUES NETO, 2013, p. 277-285).

Segundo percuciente análise de tais doutrinadores (SUNDFELD; MARQUES NETO, 2013, p. 277-285), os citados fatores de distorção da atividade jurídico-decisória pública são os seguintes:

a) alto grau de indeterminação de grande parte das normas jurídicas públicas, podendo conferir ao administrador público enorme espaço para delimitá-las segundo o mais diversificados critérios;

b) uma incerteza relativa ao verdadeiro conteúdo de cada norma, algo de certo modo inerente ao Direito;

c) uma certa tendência à formação de juízos superficiais a respeito de complexas questões jurídico-públicas; 
d) inefetividade das políticas públicas, muitas vezes decorrente da dificuldade de o poder público obter cumprimento voluntário e rápido de obrigação por terceiros;

e) instabilidade dos atos jurídicos públicos, na medida em que se submetem a um risco potencial de invalidação posterior, nas várias instâncias de controle;

f) efeitos negativos indiretos da exigência de que as decisões e controles venham de processos, relações jurídicas que podem demorar, postergando o cumprimento de obrigações e com alto custo;

g) o modo autoritário como, na quase totalidade dos casos, são concebidas e editadas normas pela Administração Pública.

A partir dessas distorções da atividade administrativa pública, os mesmos doutrinadores elaboraram medidas saneadores, que assim podem ser resumidas:

a) previsão de novos princípios jurídicos gerais, a serem observados pelas autoridades nas decisões que envolvam normas indeterminadas (arts. 20 e 21, do Projeto de Lei do Senado n. 349/2015);

b) direito à transição adequada aos administrados, quando da criação de novas situações jurídicas passivas (art. 22, do Projeto de Lei do Senado n. 349/2015);

c) criação de um regime jurídico para negociação entre autoridades públicas e particulares (art.23, do Projeto de Lei do Senado n. 349/2015);

d) criação de uma nova espécie de ação civil pública, de provimento declaratório de validade, efeito erga omnes, para dar estabilidade a atos, contratos, ajustes, processos e normas administrativas (art. 24, do Projeto de Lei do Senado n. 349/2015);

e) proibição da invalidação de atos em geral, por mera mudança de orientação (art. 25, do Projeto de Lei do Senado n. 349/2015);

f) disciplina dos efeitos da invalidação de atos em geral, com isso podendo torná-los mais justos (art. 26, do Projeto de Lei do Senado n. 349/2015);

g) impedimento a responsabilização injusta de autoridade administrativa, em caso de revisão de suas decisões (art. 27, do Projeto de Lei do Senado n. 349/2015);

h) consulta pública obrigatória para a edição de regulamentos administrativos (art. 28, do Projeto de Lei do Senado n. 349/2015), com isso se buscando a legitimidade da ação administrativa pela efetivação do princípio da participação ${ }^{1}$;

\footnotetext{
1 É inegável que tal princípio da participação é uma decorrência lógica do que se convencionou chamar, na doutrina constitucionalista, de super princípio democrático. Contudo, indo além dessa ideia, não é absurdo vislumbrar que o princípio da participação também se erige sobre o princípio da subsidiariedade, na medida em que se legitima a ação estatal pela vontade expressa do povo, elemento essencial do próprio Estado, de onde emana todo o poder deste último. Aliás, esta é lição clássica da ciência política, muitas vezes olvidada pelo gestor público que se encastela no exercício abusivo de suas prerrogativas, o que, de certa maneira, pretende o projeto de lei também combater.
} 
i) determinação da adoção de uma espécie de compensação, dentro dos processos administrativos, visando equilibrar ${ }^{2}$ benefícios ou prejuízos injustos gerados para os envolvidos (art. 29, do Projeto de Lei do Senado n. 349/2015);

Apresentadas as patologias costumeiramente notadas no agir administrativo público e pareadas as medidas curativas, conforme prescrições dos citados doutrinadores, chama a atenção uma curiosa novidade: a proposta de criação do instituto do chamado "compromisso administrativo", do qual poderá se valer o gestor público e administrados para porem fim a determinada "irregularidade, incerteza jurídica ou situação contenciosa na aplicação do direito público, inclusive quando da expedição de licença" (art. $23, \S \S 1^{\circ}$ e $2^{\circ}$, do Projeto de Lei do Senado n. 349/2015 3).

Adiantando-se o que se desfila no tópico seguinte, relativo aos objetivos deste trabalho científico, é escopo do presente o confronto do citado instrumento de compromisso com o fenômeno da desjudicialização, as competências da advocacia pública, os limites da jurisdição voluntária e os princípios de separação de poderes e republicano.

\footnotetext{
${ }^{2}$ Essa ideia da busca de um equilíbrio na ação administrativa, no sentido mesmo de distribuir seus ônus e bônus, além de ser uma decorrência lógica do princípio da razoabilidade que incide, obrigatoriamente, sobre o agir administrativo, não é algo novo. Por exemplo, é bastante consagrado o intitulado princípio da justa distribuição dos benefícios e ônus derivados da atuação urbanística, conforme clássica doutrina de José Afonso da Silva (SILVA, 2010, p. 45), cuja origem remonta à doutrina de Antonio Carceller Fernández, que o extraiu das disposições da Lei de Regimen del Suelo y Ordenación Urbana, de 1956, de Espanha, reformulada em 1975 e 1992.

${ }^{3} \mathrm{O}$ conteúdo exato do texto normativo, ora em gestação na câmara alta brasileira, que vale a pena ser integralmente transcrito, dada sua cristalina clareza, é o seguinte:
}

Art. 23. Para eliminar irregularidade, incerteza jurídica ou situação contenciosa na aplicação do direito público, inclusive quando da expedição de licença a autoridade administrativa, poderá, após consulta pública e oitiva do órgão jurídico, e presentes razões de relevante interesse geral, celebrar compromisso com os interessados, o qual só produzirá efeitos a partir de sua publicidade, na forma dos atos oficiais.

$\S 1^{\circ}$. O compromisso:

I - buscará uma solução jurídica proporcional, equânime, eficiente e compatível com os interesses gerais;

II - poderá envolver transação razoável quanto a sanções e créditos relativos ao passado, e ainda o estabelecimento de um regime de transição;

III - não poderá conferir desoneração permanente de dever ou condicionamento de direito reconhecidos por orientação geral;

IV - deverá prever com clareza as obrigações das partes e o prazo para sua efetivação; $\S 2^{\circ}$. Poderá ser requerida autorização judicial para celebração do compromisso, em procedimento de jurisdição voluntária, para o fim de excluir a responsabilidade pessoal do agente público por vício do compromisso, salvo por enriquecimento ilícito ou

crime. 


\section{OBJETIVOS}

O objetivo do presente artigo é, no bojo das discussões que tencionam o aperfeiçoamento do Projeto de Lei do Senado Federal n. 349/2015, colaborar na construção de um arcabouço normativo apto a aumentar a qualidade das decisões públicas e de seu controle.

Nesse sentido, a pesquisa enfoca o artigo 23, da citada propositura, dispositivo que versa sobre a celebração dos compromissos na aplicação do direito público, que serão denominados, para os fins deste trabalho, compromissos administrativos.

Mais especificamente, a análise recairá sobre o $\S 2^{\circ}$, do aludido artigo 23, que dispõe sobre a faculdade atribuída ao administrador público de, atendidos determinados requisitos, requerer autorização judicial, em sede de jurisdição voluntária, para a celebração do compromisso, situação que resultaria na exclusão da sua responsabilidade pessoal por vício em tal instrumento, ressalvados os casos de enriquecimento ilícito ou crime.

O dispositivo em tela será analisado sob um enfoque político-jurídico, tomando por base o fenômeno da desjudicialização, bem como as competências da advocacia pública, os limites da jurisdição voluntária e os princípios de separação de poderes e republicano, como já adiantado no tópico precedente.

Ao final do presente trabalho, se espera obter respostas quanto a viabilidade ou não da manutenção do § $2^{\circ}$, do artigo 23, no Projeto de Lei do Senado n. 349/2015.

\section{METODOLOGIA}

Como metodologia foi utilizado o método teórico, com o uso de processos dialéticos, discursivos e argumentativos, a partir de fontes doutrinárias e jurisprudenciais.

\section{DESENVOLVIMENTO DA PESQUISA}

\subsection{Da faculdade atribuída ao administrador público de requerer autorização judicial para celebrar compromisso administrativo e a efetiva exclusão de sua responsabilidade}

Segundo Carlos Ari Sundfeld e Bruno Meyerhof Salama, o contido no artigo 23, do Projeto de Lei do Senado n. 349/2015, é "honesto: já que aplicar o Direito é diferente de fazer subsunção - porque em tempos de estado social regulador não podemos mais nos dar ao luxo de viver com a fábula do "legislador racional" - então que se dê às autoridades o poder de negociar." (grifo nosso). 
E, ainda concluem: "Mas tudo com ordem, procedimento, e mais importante, com transparência. Daí, entre outras coisas, o projeto exigir 'consulta pública' e 'oitiva de órgão jurídico' como condição da celebração de compromissos." (SUNDFELD, SALAMA, in PEREIRA, 2015, p. 14).

Apesar da cuidadosa observação dos doutrinadores, não é exagerado cogitar que a criação de um mecanismo que atribui flexibilidade às autoridades administrativas, na busca de soluções negociadas com os particulares, tencionando melhor satisfazer o interesse público, parece não se compatibilizar com a ideia de obtenção, pela via judicial, de uma prévia exclusão da responsabilidade do agente pela prática do ato, consoante se explora adiante.

\subsection{Da incompatibilidade do compromisso administrativo, condicionado à ratificação pelo Poder Judiciário, face ao fenômeno da desjudicialização.}

O projeto de lei em análise, mais especificamente seu artigo 23 e respectivo $\S 2^{\circ}$, objetiva, no limite, dotar o administrador público de maior flexibilidade no desempenho de seu mister, excluindo sua responsabilidade pela celebração do compromisso administrativo, mediante a submissão do feito ao Poder Judiciário, em sede de jurisdição voluntária, para fins de obtenção de autorização.

É como se o Poder Judiciário agisse para chancelar, ratificar e, com isso, conferir validade ao compromisso administrativo.

Até se pode compreender uma intenção direcionada a conferir, provavelmente, maior segurança ao ajuste de vontades, todavia, a submissão pura e simples do compromisso administrativo à jurisdição voluntária, objetivando também exclusão da responsabilidade da autoridade administrativa, mesmo que mediante determinadas condições, de plano, sob uma perspectiva político-jurídica, pode encontrar alguns óbices e incongruências.

Segundo o "Placar da Justiça", elaborado pela Associação dos Magistrados do Brasil

(AMB), o país conta hoje com mais de 100 (cem) milhões de processos em andamento, respondendo o setor público, consoante dados tabulados pelo Conselho Nacional de Justiça (CNJ) em $2011^{5}$, por $51 \%$ (cinquenta e um por cento) do total de processos dos 100 (cem) maiores litigantes nacionais.

\footnotetext{
${ }^{4}$ Disponível em http://www.amb.com.br/novo/?page_id=23202. Acesso em 14 nov 2015.

${ }^{5}$ Disponível em http://www.cnj.jus.br/images/pesquisas-judiciarias/pesquisa_100_maiores_litigantes.pdf. Acesso em 14 nov. 2015.
} 
Evidente, nesse passo, que a opção social de resolução de litígios pela via judicial acaba por se traduzir na demora na prestação jurisdicional, vez que, conforme apontado por B. S. Santos et al (SANTOS, 1996, p. 16), os tribunais "de todos os mecanismos de resoluções de litígios disponíveis tendem a ser os mais oficiais, os mais formais, os mais especializados e os mais inacessíveis".

Em virtude disso, e como forma de fazer frente à litigiosidade que marca a sociedade brasileira, nos últimos anos diversos mecanismos de resolução extrajudicial de conflitos foram criados, dentre os quais a negociação, mediação, conciliação e a arbitragem.

Como é amplamente debatido, esses mecanismos se inserem no que se convencionou chamar de fenômeno da desjudicialização.

A desjudicialização, segundo Fernanda Holanda de Vasconcelos Brandão (BRANDÃO, 2014, p. 132) "tira do Poder Judiciário a função primeira de resolver conflitos, caracterizando-se a jurisdição como alternativa aos métodos negociais de solução de conflitos".

O referido fenômeno não é recente, havendo previsão no vetusto Decreto-lei n. ${ }^{\circ}$ 9.521/46, do juízo arbitral em questões que envolvessem a União Federal.

Esse diploma legal da década de quarenta do século passado, por seu turno, passou pelo crivo do reconhecimento de legalidade pela histórica decisão proferida pelo Ministro Olavo Bilac Pinto, do Supremo Tribunal Federal, no âmbito do Agravo de Instrumento n. ${ }^{\circ}$ $52.181 / \mathrm{GB}$.

No acórdão deste julgado, o citado ministro da Corte Suprema brasileira, reproduzindo lição de Castro Nunes, consignou a seguinte característica do juízo arbitral:

O que se assegura é o direito à jurisdição, o acesso às justiças regulares, a possibilidade ressalvada de poderem levar à Juízo a sua pretensão ou de não responderem senão em Juízo.

Ao inverso, o Juízo Arbitral supõe, no ato da sua Constituição, o acordo das partes que consentem em subtrair a causa às Justiças regulares, estando pelo que decidirem os Juízes-árbitros por eles escolhidos.

Jamais se estendeu, aqui o alhures, pudesse o compromisso arbitral constituir uma infração daquele princípio tradicional uma autorização legislativa para a instituição do Juízo Arbitral, e, em tal caso, provindo da lei, como sucede na hipótese, a subtração do litígio às justiças regulares.

Mas, o compromisso firmado com a outra parte importaria na aceitação por esta via adotada em substituição à judiciária, conservando-se assim no plano consensual a solução arbitral.

Ainda sobre a evolução do fenômeno da desjudicialização, em sentido amplo, verificase que, a partir da década de noventa do século passado, foram acentuados métodos alternativos de composição de litígios mediante a promulgação de diversas leis. Vale destacar as seguintes: 
a) Lei n. ${ }^{\circ}$ 8.954, de 13 de dezembro de 1994, que alterou dispositivos do Código de Processo Civil sobre as ações de consignação em pagamento e de usucapião;

b) Lei n. ${ }^{\circ}$ 9.514, de 20 de novembro de 1997, que, primordialmente, dispôs sobre o Sistema de Financiamento Imobiliário e instituiu a alienação fiduciária de coisa imóvel;

c) Lei n. ${ }^{\circ}$ 10.931, de 02 de agosto de 2004, sobre o patrimônio de afetação de incorporações imobiliárias, Letra de Crédito Imobiliário, Cédula de Crédito Imobiliário, Cédula de Crédito Bancário, alterando diversos diplomas legais anteriores;

d) Lei n. ${ }^{\circ}$ 11.101, de 09 de fevereiro de 2005, que regulou a recuperação judicial, a extrajudicial e a falência do empresário e da sociedade empresária;

e) Lei n. ${ }^{\circ} 11.441$, de 04 de janeiro de 2007, que alterou dispositivos da Lei $\mathrm{n}^{\mathrm{o}}$ 5.869, de 11 de janeiro de 1973 - Código de Processo Civil, possibilitando a realização de inventário, partilha, separação consensual e divórcio consensual por via administrativa ${ }^{6}$;

f) Lei n. ${ }^{\circ} 11.977$, de 07 de julho de 2009, que dispõe, principalmente, sobre o Programa "Minha Casa, Minha Vida - PMCMV" e regularização fundiária de assentamentos localizados em áreas urbanas.

A reboque dos referidos normativos, muitas outras leis foram promulgadas, prevendo mecanismos alternativos de composição de litígios envolvendo, inclusive, o Estado.

Nesse sentido, sobreveio a Lei da Arbitragem (Lei n. ${ }^{\circ}$ 9.307/1996) que, reafirmando a possibilidade da utilização da arbitragem nos conflitos envolvendo a Fazenda Pública, dispôs expressamente em seu artigo $1^{\circ}$, e $\S 1^{\circ}$ :

Art. $1^{\circ}$ As pessoas capazes de contratar poderão valer-se da arbitragem para dirimir litígios relativos a direitos patrimoniais disponíveis.

§ 1 A administração pública direta e indireta poderá utilizar-se da arbitragem para dirimir conflitos relativos a direitos patrimoniais disponíveis.

A mediação, abarcando inclusive o setor público, por seu turno, foi disciplinada pela Lei n. ${ }^{\circ} 13.140 / 2015$.

\footnotetext{
6 Denota-se neste diploma legal, em especial, a evidente intenção de se transferir a uma via processual administrativa mais célere os diversos processos de jurisdição voluntária que assoberbavam o Poder Judiciário. Ou seja, é um critério implícito informador das reformas legais a retirada de questões que não envolvam propriamente uma lide (na sua concepção mais tradicional de conflito de interesses qualificado por uma pretensão resistida), das mãos do Poder Judiciário e repasse a outros órgãos estatais dotados de fé pública, tais como os cartórios extrajudiciais 
O próprio Novo Código de Processo Civil, Lei n. ${ }^{\circ}$ 13.015, de 16 de março de 2015, prevê, em seus artigos 319, VII e 334, a utilização de mecanismos de composição, com a audiência prévia de conciliação ou de mediação.

A propósito, ainda, Juliana Bonacorsi de Palma (PALMA, in PEREIRA, 2015, p. 27) classifica o compromisso administrativo como espécie de um gênero "acordo administrativo" e realça outros tipos:

O compromisso é espécie de acordo administrativo, como os termos de compromisso utilizados pela CVM para substituir o processo administrativo sancionador, os acordos de leniência no Cade ou nos licenciamentos consensuais na seara ambiental.

Evidente, portanto, que há uma clara tentativa do legislador de municiar o cidadão, bem como o próprio Estado, de meios alternativos para a composição de conflitos, desafogando assim, o Poder Judiciário.

No campo do Direito Administrativo, Adilson de Abreu Dallari também anota ser uma tendência a possibilidade de utilização de métodos de arbitragem como solução para os conflitos na esfera do Direito Administrativo (DALLARI, v. 24, p. 63-74).

Diante de tudo o que se expôs, conclui-se que, apesar do mérito da propositura a fim de dotar o administrador público de um instrumento, consubstanciado no compromisso administrativo, fato é que a possibilidade de submissão deste instrumento ao Poder Judiciário em sede de jurisdição voluntária para a obtenção de autorização, com o fim de excluir a responsabilidade pessoal do agente público por vício do compromisso, contraria o fenômeno da desjudicialização, com um enorme potencial de inviabilizar, dado o acréscimo de serviço notoriamente conhecido, a já precarizada atividade jurisdicional.

Ademais, é relativamente esperado que o agente público em tal situação, cônscio de que a chancela judicial, em tese, excluirá sua responsabilidade por vício do compromisso, sirvase dos conceitos jurídicos indeterminados que permeiam a cabeça do artigo 23, da propositura, para fundamentar, em grande medida, todos os acordos celebrados com particulares, objetivando submetê-los ao Judiciário posteriormente.

Sob um ponto de vista bastante pragmático, também pode se descortinar uma situação inusitada, em que, diante dos diversos controles e pressões que incidem sobre o gestor público ${ }^{7}$,

\footnotetext{
${ }^{7}$ Aqui são possíveis inúmeras referências, por exemplo: Lei de Improbidade Administrativa (Lei n. 8.429/1992); Lei de Responsabilidade Fiscal, com a descrição de condutas típicas penais inclusive (Lei Complementar n. 101/2000); Lei de Inelegibilidades (Lei Complementar n. 64/1990), em nova redação que a fez ficar popularmente conhecida como a "lei da ficha limpa"; Lei dos Crimes de Responsabilidade (Lei n. 1.079/1950) voltada à responsabilização dos agentes políticos federais; o regime disciplinar político administrativo e ético parlamentar, no âmbito dos agentes públicos municipais (Decreto-Lei n. 201/1967) e, finalmente, a possibilidade de imposição de penalidades pelos Tribunais de Contas, no nível federal, estadual e municipal, nos processos de
} 
sinta-se este tentado a utilizar indiscriminadamente o novel instituto jurídico como meio de se amenizar, ou mesmo se furtar, à submissão aos citados controles.

Destarte, sob uma perspectiva política e quiçá jurídica, inviável a submissão dos tais compromissos administrativos ao Judiciário, sobretudo pelos possíveis impactos deletérios que poderá gerar ao já deficiente funcionamento do órgão jurisdicional.

\subsection{Da incompatibilidade do compromisso administrativo diante das competências da advocacia pública, dos limites da jurisdição voluntária e dos princípios de separação de poderes e republicano.}

Adentrando aos aspectos mais estritamente jurídicos da discussão, tem-se que a propositura em exame esbarra nas competências da advocacia pública, no alcance das decisões proferidas em sede de jurisdição voluntária e nos princípios de separação de poderes e republicano.

À advocacia pública, conforme previsto nos artigos 131 e 132, da Constituição Federal de 1988 (CF/88), compete a representação judicial e extrajudicial, bem como as atividades de consultoria e assessoramento jurídico aos entes estatais.

Para além das discussões acerca do caráter vinculante ou não dos pareceres e manifestações jurídicas proferidas pelos membros das carreiras da advocacia pública, é patente a competência de tais profissionais para a promoção e o controle de legalidade dos atos da administração pública, conforme bem asseverado por Diogo de Figueiredo Moreira Neto (MOREIRA NETO, 2009, p. 111-138):

Especificamente, os Advogados de Estado recebem outra investidura
especial, em cargos constitucionalmente diferenciados, que não são cargos
administrativos, mas cargos jurídicos próprios, tal como desde logo e
expressamente instituídos na própria Carta Magna, especialmente destinados
ao desempenho das funções advocatícias públicas: de promoção e de controle
de legalidade (entendida aqui em sua acepção atual e mais ampla, de
juridicidade).

Também, referida competência encontra-se prevista em diversas leis orgânicas de Procuradorias Gerais de Estados, valendo trazer a tona, em virtude de sua atualidade, algumas disposições da Lei Complementar n. 1.270, de 25 de agosto de 2015 (Lei Orgânica da Procuradoria Geral do Estado de São Paulo): 
Artigo $3^{\circ}$ - São atribuições da Procuradoria Geral do Estado, sem prejuízo de outras que lhe forem outorgadas por normas constitucionais e legais:

(...)

XV - opinar previamente à formalização dos contratos administrativos, convênios, termos de ajustamento de conduta, consórcios públicos ou atos negociais similares celebrados pelo Estado e suas autarquias, observado o disposto no artigo 45 desta lei complementar.

(...)

Artigo 44 - São atribuições das Consultorias Jurídicas:

(...)

IV - manifestar-se sobre a constitucionalidade e a legalidade de atos administrativos e de anteprojetos de lei de interesse dos órgãos e entidades atendidos.

E, conforme bem notado por Alexsander Aparecido Gonçalves, a advocacia pública pode até "fazer prevalecer seu entendimento mesmo que contrário ao da Administração Pública, celebrando acordos, reconhecendo pedidos ou não interpondo recursos em processos judiciais”.

A razão disto seria o fato que a vontade ou interesses do administrador público não cerceiam o entendimento do advogado público, até porque se está diante de uma instituição que “defende o Estado na sua mais ampla acepção, não o seu representante político, ou seja, promove a advocacia de Estado, não de Governo”. (GONÇALVES, 2010, P. 43-46)

Assim, a prevenção da responsabilidade do agente público pela celebração de um ajuste, já se encontra, em certa medida, bastante abarcada pela análise prévia do referido documento pela advocacia pública, em sede de controle de legalidade.

A previsão da faculdade de submissão do "compromisso na aplicação do direito público" ao Poder Judiciário, além de ser potencialmente prejudicial ao funcionamento do órgão judicante, é despicienda, vez que a prevenção da responsabilidade do agente público decorre, em grande medida, do controle de legalidade do ato administrativo, normalmente exercido previamente à realização deste último, pela advocacia pública.

Por outro giro, fato é que a propositura não trata especificamente de uma prevenção de responsabilidade do agente público pela celebração do compromisso administrativo, mas sim da exclusão de referida responsabilidade.

Entretanto, a exclusão da responsabilidade do agente público, mediante submissão do acordo administrativo à jurisdição voluntária pode encontrar três óbices:

a) os limites ou o alcance das decisões proferidas em sede de jurisdição voluntária;

b) o contraste entre a possibilidade de análise, pelo Judiciário, do juízo de conveniência e oportunidade administrativa na celebração do ajuste e o princípio magno de separação de poderes; 
c) o contraste entre a pretensa exclusão da responsabilidade do agente público, mediante chancela judicial, e o princípio republicano.

Primeiramente, em relação aos contornos da jurisdição voluntária, é mister consignar que no seu âmbito não há lide, mas sim acordo entre as partes, cujo aperfeiçoamento, consoante observado por Daniel Amorim Assumpção Neves (NEVES, 2013, p. 33), depende da intervenção judicial.

Fincada tal premissa, e passando-se à discussão de fundo, tem-se que a questão da autorização judicial para a celebração do ajuste, como mecanismo de exclusão da responsabilidade do agente público, parece estar intrinsecamente ligada à "coisa julgada".

É dizer: referida exclusão da responsabilidade decorreria do fato de que, uma vez transitada em julgado a decisão judicial autorizadora da celebração do ajuste, não haveria mais como se perquirir acerca da responsabilidade da autoridade administrativa, em vista da questão já se encontrar acobertada pela imutabilidade da coisa julgada. Entretanto, há de se mencionar que, independentemente das teorias a respeito da natureza jurídica da jurisdição voluntária, a decisão dela decorrente não possui o alcance pretendido pela propositura.

De fato, consoante cediço, as teorias a respeito da natureza jurídica da jurisdição voluntária se subdividem em duas, a primeira denominada "administrativista" e a outra intitulada "revisionista".

Para os adeptos da teoria administrativista, consoante observado por Daniel Amorim Assumpção Neves (NEVES, 2013, p. 32), não há exercício de atividade jurisdicional na chamada jurisdição voluntária. Já, para a teoria revisionista, "apesar de contar com peculiaridades que a distinguem da jurisdição contenciosa, na jurisdição voluntária o juiz efetivamente exerce a atividade jurisdicional".

A adoção de uma ou outra teoria traz repercussões diretas em relação ao alcance das decisões judiciais, mais especificamente no que tange à coisa julgada.

Para aqueles que seguem a corrente administrativista, não havendo exercício de atividade jurisdicional no âmbito da jurisdição voluntária, os efeitos de suas decisões, consoante observado por Luiz Rodrigues Wambier et al (WAMBIER, 2006, p. 41) não são os mesmos da atividade jurisdicional típica, "não produzindo, por exemplo, coisa julgada material".

Já para os que seguem a teoria revisionista, à luz do artigo 1.111 do Código de Processo Civil $^{8}$ a decisão proferida em sede de jurisdição voluntária produz coisa julgada material, com

\footnotetext{
${ }^{8}$ Eis o conteúdo do dispositivo legal:
} 
alguns contemperamentos, consoante observado por Daniel Amorim Assumpção Neves (NEVES, 2013, p. 35):

Será mesmo que tal dispositivo afasta a coisa julgada material da sentença proferida na jurisdição voluntária? Acredito que não.

A técnica utilizada pelo legislador no art. 1.111 do CPC foi a mesma usada no art. 471, I, do CPC, que trata da coisa julgada em sentença que tenha por objeto relações continuativas como a sentença condenatória de alimentos, ou ainda a que fixa o valor do aluguel em demanda revisional. A melhor doutrina defende que nesses casos existe coisa julgada material, e que mantida a situação fático-jurídica deverão ser mantidas também a imutabilidade e a indiscutibilidade próprias dessa decisão.

A modificação superveniente, prevista em lei, cria uma nova causa de pedir (fatos e fundamentos jurídicos do pedido), de maneira que a eventual mudança da sentença não violaria a coisa julgada material. Com uma nova causa de pedir, desaparecem a tríplice identidade e, conseqüentemente, os efeitos negativos da coisa julgada material.

Destarte, adotada a teoria administrativista, restaria prejudicada a tentativa do legislador de excluir a responsabilidade da autoridade administrativa por vício no compromisso, porque a decisão que autorizaria sua celebração, não produziria coisa julgada material.

Adotada a teoria revisionista, possível seria a revisão da decisão judicial, desde que presentes motivos supervenientes (art. 1.111, do Código de Processo Civil).

Oportuno registrar, neste ponto, que a deflagração do processo legislativo que culminou na propositura, se deu na vigência do Código de Processo Civil de 1973.

O Novo Código de Processo Civil, produto da Lei ${ }^{\circ} 13.105 / 2015$, por seu turno, não reproduziu o citado artigo 1.111, do antigo Código de Processo Civil, restando, destarte, prejudicada a corrente revisionista.

Remanesceriam, portanto, duas correntes, a saber: a administrativista, e outra que entende fazer coisa julgada a decisão proferida em sede de jurisdição voluntária.

No plano da corrente administrativista, resta evidenciado que a autoridade administrativa não poderia se escudar na coisa julgada, como forma de ver excluída a sua responsabilidade por vício no compromisso, tal como preconizado pelo $\S 2^{\circ}$, do artigo 23 , da propositura.

A adoção da segunda corrente, por seu turno, não valida, por si só, o preceito previsto no citado artigo $23, \S 2^{\circ}$, do projeto de lei do Senado Federal.

Art. 1.111. A sentença poderá ser modificada, sem prejuízo dos efeitos já produzidos, se ocorrerem circunstâncias supervenientes. 
Superada a questão quanto ao alcance das decisões proferidas em sede de jurisdição voluntária, desemboca-se na análise da possível ofensa aos princípios de separação de poderes e republicano.

Importante salientar, de plano, que a intervenção judicial em sede de jurisdição voluntária não é passiva, meramente protocolar, pois o Juiz poderá ainda solucionar o caso por meio da equidade, por força da previsão contida no artigo 723, par. único, do Novo Código de Processo Civil.

Sobre o assunto, esclarece Daniel Amorim Assumpção Neves (NEVES, 2013, p. 30) que "o juiz não é obrigado a observar o critério da legalidade estrita, podendo adotar em cada caso concreto solução que reputar mais conveniente".

Ora, a possibilidade de o juiz adentrar no mérito da questão posta sob sua análise se mostra incompatível com o princípio magno de separação de poderes, vez que o "compromisso administrativo", previsto no artigo 23 , da propositura objeto desta análise, encerra um juízo de conveniência e oportunidade do Poder Executivo.

Todavia, ainda que superado o entendimento quanto à impossibilidade do juízo adentrar ao mérito do "compromisso administrativo", a previsão constante da propositura não tem o alcance pretendido, vez que, a exclusão da responsabilidade do agente público encontra óbice no princípio republicano.

De fato, conforme anotado por Uadi Lammêgo Bulos (BULOS, 2008, p. 388), o princípio republicano "consagra a ideia de que representantes eleitos pelo povo devem decidir em seu nome, à luz da responsabilidade (penhor da idoneidade da representação popular)".

Ínsito, portanto, ao conceito de República, a responsabilidade dos agentes públicos, que devem responder por todos os danos a que derem causa.

Assim, a ideia de que a chancela do Judiciário ao acordo constituir-se-ia num meio de pré-excluir a responsabilidade do agente público, não parece se amoldar ao princípio republicano que permeia todo o funcionamento do aparato estatal.

Ainda, poder-se-ia vislumbrar, na espécie, a seguinte questão: sobre qual agente público recairia a responsabilidade pelo vício no compromisso administrativo? Sobre a autoridade administrativa responsável por sua elaboração ou sobre o juiz que autorizou sua celebração?

Portanto, se a pretensão da criação do compromisso administrativo vem na esteira de se propiciar uma maior segurança na ação administrativa, diante do aqui colocado, se estaria contribuindo para uma situação de total insegurança jurídica, em flagrante contrariedade ao $\begin{array}{lllll}\text { objetivo do próprio } & \text { projeto } & \text { lei. }\end{array}$ 


\section{CONCLUSÕES}

O presente artigo objetivou analisar, à luz do fenômeno da desjudicialização, das competências da advocacia pública, dos limites da jurisdição voluntária e dos princípios da separação de poderes e republicano, a faculdade atribuída à autoridade administrativa de requerer autorização judicial para celebrar "compromisso com os interessados" e a possível exclusão de responsabilidade daí advinda, prevista no artigo $23, \S 2^{\circ}$, do Projeto de Lei do Senado n. ${ }^{\circ}$ 349, de 2015, que inclui, na Lei de Introdução às Normas do Direito Brasileiro (Decreto-lei n. ${ }^{\circ}$ 4.657, de 1942), disposições sobre segurança jurídica e eficiência na criação e aplicação do direito público.

Apesar dos inegáveis avanços que se cogita que o referido compromisso administrativo possa proporcionar ao funcionamento da Administração Pública, atribuindo a necessária flexibilidade às autoridades administrativas na busca de soluções negociadas com os particulares, fato é que a faculdade de submissão do acordo ao Poder Judiciário, para fins de obtenção de autorização, objetivando excluir responsabilidades, constitui uma opção política em descompasso com o momento histórico atual, que é marcado pelo fenômeno da desjudicialização, ou seja, pela criação de métodos alternativos de resolução de conflitos, sem a participação do órgão judicante estatal.

Demais disso, a submissão de tais compromissos ao Poder Judiciário tem um enorme potencial de inviabilizar, dado o acréscimo de serviço, a já precarizada atividade jurisdicional e, portanto, a perpetuação de situações de conflito entre o poder público e o administrado, com evidente déficit de eficiência às ambas as partes envolvidas.

A intenção de se criar o compromisso administrativo também pode não se sustentar pela previsão da prevenção da responsabilidade do agente público, vez que ela se encontra abarcada pelo controle prévio de legalidade do ato pela advocacia pública.

Nos mesmos moldes, a submissão do compromisso administrativo à jurisdição voluntária pode culminar na impossibilidade de se atingir o fim pretendido, de se alcançar a exclusão da responsabilidade do agente público, primeiramente pelo fato da decisão proferida em tal sede não produzir coisa julgada, tal como preconizado pela corrente administrativista, ou, ainda que a produzindo, ser incompatível com os princípios de separação de poderes e republicano.

Assim, outra não é a conclusão do que pela inviabilidade político-jurídica de se manter a propositura com o compromisso administrativo previsto no $\S 2^{\circ}$, do artigo 23 , no texto do Projeto de Lei do Senado n. 349/2015, que inclui, na Lei de Introdução às Normas do Direito 
Brasileiro (Decreto-lei n. ${ }^{\circ}$ 4.657, de 1942), disposições sobre segurança jurídica e eficiência na criação e aplicação do direito público.

Noutras palavras, pode se considerar de duvidosa eficácia o compromisso administrativo nos moldes em que está vazado na propositura legislativa.

\section{REFERÊNCIAS}

ASSOCIAÇÃO DOS MAGISTRADOS DO BRASIL - AMB. Placar da justiça. Disponível em <http://www.amb.com.br/novo/?page id=23202 $>$. Acesso em: 14 nov. 2015.

BRANDÃO, Fernanda Holanda de Vasconcelos. Advocacia negocial: promoção do acesso à justiça pela desjudicialização dos conflitos. João Pessoa: A União, 2014.

BRASIL. Decreto-lei n. 4.657, de 4 de setembro de 1942, com redação dada pela Lei n. 12.376, de 30 de dezembro de 2010. Lei de Introdução às Normas do Direito Brasileiro. Diário Oficial da União, Brasília, 04 de setembro de 1942. Disponível em: <http://www.planalto.gov.br/ccivil_03/Decreto-Lei/Del4657compilado.htm>. Acesso em 26 de nov. 2015.

. Lei n. 5.869, de 11 de janeiro de 1973. Código de Processo Civil. Diário Oficial da União, Brasília, 11 de janeiro de 1973. Disponível em: <https://www.planalto.gov.br/ccivil_03/LEIS/L5869.htm>. Acesso em 26 de nov. 2015.

Lei n. 13.105, de 16 de março de 2016. Código de Processo Civil. Diário Oficial da União, Brasília, 16 de março de 2016. Disponível em: <http://www.planalto.gov.br/ccivil_03/_Ato2015-2018/2015/Lei/L13105.htm>. Acesso em 18 de mar. 2016.

BULOS, Uadi Lammêgo. Curso de direito constitucional. $2^{\mathrm{a}}$ ed. São Paulo: Saraiva, 2008.

CONSELHO NACIONAL DE JUSTIÇA. Os 100 maiores litigantes. Brasília mar 2011.

Disponível em $\quad$ http:// Dwww.cnj.jus.br/images/pesquisasjudiciarias/pesquisa_100_maiores_litigantes.pdf $>$. Acesso em: 14 nov. 2015. 
DALLARI, Adilson de Abreu. Os poderes administrativos e as relações jurídicoadministrativas. Revista Trimestral de Direito Público, v. 24, p. 63-74.

GONÇALVES, Alexsander Aparecido. A advocacia pública e suas funções institucionais. Fórum Administrativo - Direito Público - FA, Belo Horizonte, ano 10, n. 108, p. 43-46. Fev. 2010

MOREIRA NETO, Diogo de Figueiredo. A responsabilidade do advogado de estado, in: ORDACGY, André da Silva; FIGUEIREDO, Guilherme José Purvin (orgs.). Advocacia de estado e defensoria pública: funções essenciais à justiça. Curitiba: Letra da Lei, p. 111-138, 2009.

NEVES, Daniel Amorim Assumpção. Manual de direito processual civil. $5^{\text {a }}$ ed. São Paulo: Método, 2013.

PEREIRA, Flávio Henrique Unes (coord.). Segurança jurídica e qualidade das políticas públicas, Brasília: Senado Federal, 2015. Disponível em: <http://antonioaugustoanastasia.com.br/wp-content/uploads/2015/09/segurancajuridica.pdf>. Acesso em: 27 mar. 2016

SANTOS, B.S. et al. Os tribunais nas sociedades contemporâneas. Revista Brasileira de Ciências Sociais, v.11, n.30, São Paulo, fev. 1996. Disponível em: <http://www.anpocs.org.br/portal/publicacoes/rbcs_00_30/rbcs30_07.htm>. Acesso em: 14 nov. 2015.

SÃO PAULO. Lei Complementar n. 1.270, de 25 de agosto de 2015. Lei Orgânica da Procuradoria Geral do Estado de São Paulo. Diário Oficial do Estado de São Paulo, São Paulo, 25 de agosto de 2015. Disponível em: $<$ http://dobuscadireta.imprensaoficial.com.br/default.aspx?DataPublicacao=20150826\&Cader no=DOE-I\&NumeroPagina=1>. Acesso em 26 de nov. 2015.

SILVA, José Afonso da. Direito Urbanístico Brasileiro, 6ª ed. São Paulo: Malheiros Editores, 2010 . 
SUNDFELD, Carlos Ari; NETO, Floriano de Azevedo Marques. Uma nova lei para aumentar a qualidade jurídica das decisões públicas e de seu controle, in: SUNDFELD, Carlos Ari (org.). Contratações públicas e seu controle. São Paulo: Malheiros, p. 277-285, 2013.

WAMBIER, Luiz Rodrigues; ALMEIDA, Flávio Renato Correia; TALAMINI, Eduardo. Curso avançado de processo civil. $8^{\text {a }}$ ed. São Paulo: Revista dos Tribunais, 2006. 